\title{
The Role and Practice of Red Genes in National Defense Education in Colleges
}

\author{
Shengxian $\mathrm{Gu}$ \\ Department of Human Resources, Changshu Institute of Technology, Changshu, Jiangsu 215500, \\ China \\ gsx800800@163.com
}

\begin{abstract}
The red gene is a good will quality and lofty spirit formed by our party and our army in the practice of revolution, which embodies the party's fine revolutionary tradition and collective wisdom. The national defense education work of Changshu Institute of Technology combines the characteristics of the school, grasps the spirit of the times and students' own interests, and explores new ideas for integrating red genes into the work. It has carried out a process of thinking leadership, organization leading, system leading, demonstration leading and resource integration. A series of practical explorations.
\end{abstract}

Keywords: national defense education; red gene; path; practice.

\section{Introduction}

It is the fundamental task of ordinary colleges and universities to train builders and successors of the socialist cause. As one of the school's functional departments, the People's Armed Forces of the University shoulders the heavy responsibility of cultivating and educating and guiding college students, as well as the school's military training organization, college student recruitment, campus national defense education work and publicity. Doing a good job in national defense education is an important way to improve and improve the national defense mobilization, cultivate military reserve forces, improve the national defense security concept, and promote the overall improvement of college education.

The red gene is the lofty communist spirit, the good will, the fine tradition and the style formed by our Party and our army in the unyielding revolution and struggle. It has been integrated into the blood of the Chinese Communists and has become each The unique spiritual power of a communist. In the new era of the progress of the times and social development, the integration of red genes into the national defense education of colleges and universities, leading the development and practice of national defense education in colleges and universities, has a very lofty and important significance.

\section{The Significance of the Education and Inheritance of Red Genes for College Students' Education and Guidance}

In the group of college students, the red gene represented by the red boat spirit, Jinggangshan spirit, Yan'an spirit, and the spirit of the Long March is inherited. Red education can continue to stimulate the faith of young college students, which will help them to understand the history of the party history and strengthen their ideals. Faith also helps to improve moral literacy and strengthen cultural confidence.

\subsection{Inheriting Red Genes in College Students' Education Helps Guide Young College Students to Understand the History of the Party History.}

The red gene is the fine style and good quality formed by the party and the army in the stage of revolution, struggle, state construction and reform. The process of red gene inheritance is a great process of party and state construction and development. Carrying out the inheritance and education of red genes among young college students will greatly promote the further understanding of the history of the party and the history of the country, and it will also greatly promote the correct understanding of history and the formation of correct historical views and values. This work is 
beneficial to the growth of college students themselves and has great and far-reaching significance for the future and development of the country and the nation.

\subsection{Inheriting Red Genes in College Students' Education Helps Guide Young College Students to Strengthen their Ideals and Beliefs.}

Although the red gene is a unique product of the revolutionary struggle period, its connotation will continue to be enriched with the progress of the times and the development of society. Today, the red gene has also become the carrier of the Chinese Communist Party's inheritance of ideals and beliefs. With the continuous advancement of the economic globalization of Jincheng, various bad ideas and concepts from the West continue to value the values and ideals of college students. Inheriting the red gene in the college student group will further play the role of the red gene in the subtle influence, help the university students to further strengthen their ideals and beliefs, and strive to realize socialism with Chinese characteristics in the new era.

\subsection{Inheriting Red Genes in College Students' Education Helps to Improve the Moral Literacy of Young College Students.}

Contemporary college students have never experienced the hardships and poverty-stricken life during the struggle period and the early days of the founding of the People's Republic of China, and lacked a profound understanding of the party's hard struggle history and the hard times of the country. Inheriting red genes among young college students helps them to feel the patriotic feelings that the revolutionary predecessors formed during the hard years, not afraid of sacrifice, practical dedication, and unremitting efforts to realize the great rejuvenation of the Chinese nation. Understand the profound connotation of the red gene and improve its moral cultivation.

\section{The Role of Red Genes in the Role of National Defense Education in Colleges and Universities}

The work of national defense education in colleges and universities is an important part of national defense mobilization and reserve force construction. His job responsibilities are to organize faculty and staff to carry out national defense education, organize student military training and military theory teaching, do well in college students' recruitment and demobilization, and promote the main theme. In the national defense education work of colleges and universities, the red gene can be integrated into the work of cadre team building, practice carrier innovation, and superior resource integration.

\subsection{Improve and Enrich the Ranks of National Defense Education Cadres, and Give Full Play to the Main Role of Party Members and Teachers in the Red Genetic Education.}

As the saying goes, "The train runs fast, it depends on the headband, the team is not strong, the key is in the squad leader." The key to improving the effectiveness of national defense education in the red gene inheritance education is to equip a strong team of national defense education cadres. The cadre team is the most direct executor and decision-maker of grassroots work. Whether it can play a vanguard and exemplary role is the key factor for maximizing the positive role of red genes in national defense education. In addition, it is necessary to strengthen the training and study of the cadre team and improve their theoretical training and business capabilities.

\subsection{Fully Rely on the Student Backbone Team, Play the Role of the Student Backbone in the Red Gene Inheritance.}

The student management and education work in colleges and universities relies mainly on the role and effectiveness of teachers in their work, but the strength of teachers is limited. With the help of the strength of the student backbone team, it is particularly important in the work to play their role in the national defense education work and the inheritance of the red genetic education. First, focus on the good political quality of the student party members, through their own understanding of the red gene, in-depth publicity and dissemination of red genes among college students; second, in various 
educational activities and practices, the student cadre team can act Very good organizer and implementer.

\subsection{Use Red Practice Activities as a Carrier to Expand the Influence and Coverage of Red Genes in National Defense Education.}

The most effective way to carry out the dissemination and education of red genes in colleges and universities is the combination of educational guidance and practical influence. It is necessary to organize educational and publicity activities with the righteousness and theme, and to organize relevant practical activities. Through various red practice activities, attract more students to pay attention to and participate in the red education publicity activities, and finally achieve the purpose of promoting and inheriting the red spirit and red genes.

\section{The Practical Path of the Combination of National Defense Education Work and Red Genes}

Under the guidance of the new era and new ideas, the work of human and military should open up working ideas, innovate working methods, give play to its own advantages, and explore the practical road of combining national defense education with red genes.

\subsection{Play the Role of the Red Gene in the National Defense Education Work.}

In the actual work, we firmly grasped all kinds of opportunities such as the recruitment and mobilization of the whole school, the spirit of the 19th National Congress and the study of the national flag, and the state's advanced ideas and excellent theories. The political consciousness and theoretical level of the Wushu teachers also promoted the red spirit among the teachers and students of the whole school, and fully played the role of the grassroots battle fortress of the Ministry of Human Resources and Armed Forces.

\subsection{Play the Leading Role of the Organization of Red Genes in National Defense Education.}

Party members should be equipped as military cadres, and the People's Party branch should be established. The Party branch of the People's Armed Forces has become the core of uniting the masses, the school that educates party members, and the fortress that overcomes difficulties. It has played an extremely important role in the work. In addition, the Ministry of Human Resources and Armed Forces must also seize the students of the veterans, the national flag class, the National Defense Education Work Association, etc., in which to build a special group branch, theoretical study and propaganda group, and use the advanced nature of outstanding party cadres to promote the student organization and all students. Red spirit, inheriting the red gene.

\subsection{Play the Role of the Red Gene in the National Defense Education Work.}

A good system can improve work efficiency, stimulate work dynamism, and strengthen work style. It is necessary to make full use of the institutional advantages of the party organization, and take advantage of the opportunity of the party members' democratic appraisal meeting, the party branch branch committee meeting, and the party members meeting to promote the national defense education work to innovate steadily in the light of inheriting the original excellent practices. It is also necessary to combine the characteristics and advantages of the school to establish a work incentive mechanism with school-based characteristics, including college students' recruitment encouragement policy, military training work evaluation policy, national defense education work knowledge contest reward policy, etc., so that it can develop into a red gene and national defense education work. New elements in the system.

\subsection{Play a Leading Role in the Demonstration of Red Genes in National Defense Education.}

The red spirit played an indelible role in the ultimate victory of the Chinese revolution. We should attach importance to the promotion of advanced models, through the combination of traditional 
propaganda columns and new media means, and plan to publicize the advanced teachers and students in the recruitment, military training, national defense essays, patriotic education and other activities to expand the red spirit. The spread of coverage, efforts to internalize the red spirit into the spirit of college students themselves.

\subsection{Bring into Play the Resource Advantages and Functions of the Red Education Base Inside and Outside the School.}

The Changshu Institute of Technology Changshu Institute of Technology's People's Armed Forces Department plans to strengthen contact with the local red education base, and strives to use the Shajiayu Red Education Base and the Changshu Revolutionary Martyrs Memorial Hall as a practice position. Regularly organize students to carry out educational activities, cherish the memory of the martyrs and recall the revolutionary history., inherit the red gene.

\section{Summary}

Colleges and universities are responsible for cultivating modern talents with strong political consciousness, good will, professional quality and good sense of innovation. They are the main front for cultivating qualified socialist builders and successors. Strengthening the inheritance of red genes in the national defense education work of higher education institutions can make red genes show new value in the new era, and can further build a spiritual foundation in higher education institutions, implement the fundamental tasks of Lide Shuren, and condense All the teachers and students are eager to train the socialist qualified builders and reliable successors with Chinese characteristics.

\section{Acknowledgments}

This paper is the result of the phased research of the 2018 student military training project of Jiangsu Province, "The research on the leading role of the 'red gene' in the armed work of ordinary colleges and universities".

\section{References}

[1]. Liu Dan. On the inheritance and practice of red genes[J]. Journal of Xi'an University of Political Science, 2015(1): 25-28.

[2]. Dai Mouyuan, Bu Huaping. Analysis of the Path of Inheriting Red Genes in National Defense Education in Colleges and Universities[J]. Curriculum Education Research, 2018(11): 12-13.

[3]. Shi Yuzhu. Exploring the Path of Inheriting Red Genes in College Ideological and Political Education[J].Journal of Karamay, 2015(5):53-57. 